This is the accepted verison of the article "Obukhova E, Rubineau B. Market Transition and Network-Based Job Matching in China: The Referrer Perspective. ILR Review. July 2020.

doi:10.1177/0019793920937234" this version is licensed under a CC-BY-NC-ND license

\title{
Market transition and network-based job matching in China:
}

The referrer perspective

\section{(Accepted to Industrial Labor relations Review)}

https://doi.org/10.1177/0019793920937234

\author{
Elena Obukhova \\ elena.obukhova@mcgill.ca \\ McGill University
}

\section{Brian Rubineau}

brian.rubineau@mcgill.ca

McGill University

Keywords: referrals, social networks, labor markets, market transition, China

Acknowledgments. This paper benefited from discussion with and comments from Matthew Bidwell, Roberto Fernandez, Minjae Kim, Yonghoon Lee, Peter Sherer; seminar participants at the University of Chicago, Massachusetts Institute of Technology, Hong Kong Baptist University, Hong Kong University of Science and Technology, and McGill University; and conference participants at the American Sociological Association, Academy of Management, INSNA Sunbelt, GRAI 3ième Conférence en Recherche International, HEC Montreal, the Junior Faculty Organizational Theory Conference at the University of Toronto, the People and Organizations Conference at the University of Pennsylvania and the Economic Sociology Conference at Georgetown University. We are also grateful to Li Lulu, Tianfu Wang, and Letian Zhang for help with development of the referrer module for the Chinese General Social Survey. The usual disclaimer applies.

Corresponding author: Elena Obukhova, Bronfman Building, 1001 rue Sherbrooke Ouest, Montreal, Quebec, Canada H3A 1G5. 


\title{
Market transition and network-based job matching in China: The referrer perspective
}

\begin{abstract}
To expand our understanding of how network-based job matching responds to market development, we investigate network matching in China. We examine this question from the perspective of referrers, those who share information about job opportunities with potential job candidates. Using unique data from a population survey and leveraging inter-provincial differences in market development, we show that market development has a negative association with individuals' propensity to share job information. However, people who work at firms offering a referral bonus and at private firms are more likely to share information and share it with more people, and the number of such employers increases with market transition. This can produce a positive association between market development and overall prevalence of job information-sharing. Our results clarify the role employer-side processes play in job information-sharing and carry important implications for our understanding of network matching.
\end{abstract}




\section{Market transition and network-based job matching in China: The referrer perspective}

\section{INTRODUCTION}

It is common knowledge that social networks play a significant role in labor markets. Many streams of research have explored network-based job matching, or network matching for short. However, most of this knowledge comes from developed market economies where market institutions are stable and mature. This limits our ability to understand how network matching responds to institutional change. The development of market economies in formerly socialist countries, such as China, Russia and East Germany, provide an unparalleled opportunity to observe the dynamic interdependencies between market development and network matching. Accordingly, in this paper we ask: What effect did the transition from a planned economy to a market economy in China have on network matching?

Extant research on network matching in transition economies makes conflicting predictions about this question. Some scholars suggest that as formerly socialist economies transition from planned to market economies, network matching decreases. These theories propose that as markets develop, formal labor market intermediaries replace state assignment to jobs, and the importance of network matching declines. However, many empirical studies find the opposite: network matching increases with market development. One compelling explanatory mechanism for these results is that with transition, employers adopt network recruitment, or practices that encourage their employees to share information about job opportunities with their contacts. 
To resolve these conflicting expectations, we adopt the perspective of referrersthose individuals who share information about a job opportunity with a potential job candidate. ${ }^{1}$ The referrer perspective offers an opportunity for gaining novel insights into network matching relative to prior approaches. Because prior research has focused on job-finding methods, i.e. asking respondents how they found their current job, they are necessarily based on post-hire outcomes. As such, post-hire observations of job-finding methods offer at best noisy and at worst biased insight into pre-hire processes. Specifically, adopting a referrer perspective allows us to analytically disentangle the effect of market development on individuals' propensity to share job information from the effect of an increase in the number of employers adopting practices encouraging employees to share job information.

The data for our study come from a one-of-a-kind module on job informationsharing designed by the authors that was included in the 2012 Chinese General Social Survey (CGSS), a representative population survey of residents in 29 provincial-level units in China. This is the first time to our knowledge that data on job informationsharing has been collected in a large-scale survey in China. To examine the effects of market development on network matching, we leverage the substantial regional variation in market development. We capture inter-provincial variations in market development using a measure developed by China's National Economic Research Institute that is commonly used to study the effects of institutional variation. Combining these two data

\footnotetext{
${ }^{1}$ We use referring as a synonym for the sharing of job information with prospective job candidates. Thus, referring does not require that the employer has a formal referral program. In fact, under our definition, referrers can share information about jobs with employers other than the referrers' own, a feature we exploit in our analysis.
} 
sources allows us to gain unique insights into how pre-hire processes obscured in many previous studies vary with market development.

\section{MARKET TRANSITION AND NETWORK MATCHING}

\section{Theories and evidence for network matching decline}

Two existing theoretical perspectives suggest that market development reduces network matching. The first is rooted in market transition theory (Nee 1989; Gurthrie 1998, Benton et al. 2015). The key intuition here is that state planning engendered widespread reliance on social networks to access resources, and that this reliance declines with market development. Contrary to the rhetoric of state planning, in planned economies the leveraging of social connections (known as guanxi in China and blat or svyazi in Russia), although illegal, was widespread and socially tolerated (Lebedeva 1998; Michailova and Worm 2003). For example, in Communist Neo-Traditionalism (1986), Andrew Walder argues that the distribution of scarce resources through personal networks, and the relationships of loyalty and dependency that this created, were the building blocks of regime stability in Communist China.

Not surprisingly, under state planning social networks played an important role in labor markets (for Hungary, see Böröcz and Southworth 1998; for German Democratic Republic, see Völker and Flap 1999; for China, see Bian 1994, 1997). For example, well into the 1980s, China had an assignment system under which the state assigned job candidates to work units (as organizations were known in China's planned economy). Formally, job candidates had little choice in which work units they were assigned. Informally, job candidates used social networks to circumvent the state assignment 
system to obtain a more desirable job or to facilitate a job change (Bian 1994, 1997). This was typically done by trying to locate a high-status contact who could connect them to a decision-maker who could influence the assignment process. While officially illegal, this use of network to influence job assignments was nevertheless common.

Market transition theory (Nee 1989) predicts that as market economies replace planned economies as the means for allocating resources, people are able to access resources through the market and no longer need to resort to social networks. In the sociology of China, this prediction has become known as the "declining significance of guanxi” thesis (Guthrie 1998). In terms of labor markets, the dismantling of the state assignment system means that job candidates no longer need to rely on social networks to try to alter their job assignment, and instead can apply for jobs directly with their preferred employers or in a chosen field. We might also expect that a decline in the dependence on networks to get things done would reduce the incentive for potential referrers to recommend job candidates in hopes of creating a reciprocal relationship that the referrer could call upon for favors in the future.

The second stream of research that predicts a negative relationship between market development and network matching is rooted in the literature on institutional holes (e.g. Yakubovich and Kozina 2000; Bian 2002; Yakubovich 2005). Broadly in line with the arguments of market transition theory that the introduction of markets reduces the importance of network exchanges, scholars in this camp suggest that market transition temporarily increases economic uncertainty, thus creating a short-term increase in the use of networks. In labor markets, these scholars argue, the dismantling of the state assignment system creates institutional holes, or gaps in formal institutions, which job 
candidates fill by using social networks. For example, because few formal channels are available for the dissemination of information about job openings or the application process, job candidates seek this information through their social networks (Bian 2002).

Institutional holes theory predicts that after this initial increase in network matching, as the market continues to develop, the importance of network matching declines. While market transition theory focuses on the dismantling of state planning, institutional holes theory points to the emergence and maturation of formal market institutions as the causal driver of the decline in network matching. Formal market institutions can reduce the uncertainty leftover from the dismantling of state institutions. In labor markets, a variety of formal intermediaries, such as job fairs, employment agencies, and web-based employment news sites might emerge to fill in institutional holes and reduce uncertainty. With the growth of these formal intermediaries, job candidates no longer need to rely on social networks to obtain information about job openings. Referrers might also feel less pressure to help job candidates who have other job search options open to them.

Empirical research has provided some evidence the decline in network matching in transition economies because tapping social networks becomes a job search method of last resort (Loury Datcher 2006; Pellizzari 2010). For example, in a large-scale study, Benton et al. (2015) find that in East Germany the use of social networks decreased with transition. Likewise, some evidence from China suggests that when markets are developed, job candidates prefer to find jobs without resorting to networks. In ethnographic work focusing on graduating university students in China, a labor market where state assignment was dismantled in the 1990s and a variety of formal sector 
intermediaries (including university careers offices that can leverage their institutional linkages to employers) have stepped in to fill institutional holes, Hanser (2002) finds that Chinese college students feel that using connections to search for jobs is undesirable and even stigmatized. Relatedly, Obukhova (2012) finds that in elite universities, job offers that students received through connections were no better than offers received through the markets.

\section{Theories and evidence for network matching increase}

While much existing theory predicts a negative relationship between market development and network matching and some studies report evidence consistent with this view, there are also many large-scale empirical studies that find a positive relationship between market development in transition economies and network matching (e.g. Gerber and Mayorova 2010; Zhao 2013; Tian and Lin 2016; Bian 2018). Focusing on China and pooling data from three large-scale surveys, Tian and Lin (2016) find that while $15 \%$ of those who found jobs in 1978 did so through networks, that figure jumped to $45 \%$ in 2008. Drawing on data from several studies he has conducted, Bian (2018) also finds that the proportion of jobs found through networks nearly doubled between 1978 and 2009. Studies in Russia (e.g. Yakubovich and Kozina 2000; Gerber and Mayorova 2010) report similar results.

One compelling explanation for these findings is that market transition is associated with an increase in network matching specifically driven by employers' use of network recruitment (e.g. Gerber and Mayorova 2010; Nee and Opper 2012). Network recruitment can involve a variety of formal and informal practices adopted by employers 
that encourage employees to share information about job opportunities with their contacts. For example, employers can incentivize such information-sharing through formal referral programs, and might even offer a bonus to those who make referrals. Network recruitment can also be informal, but still employer-supported. For example, employers might simply let their employees know about positions that need to be filled. They might also have informal understandings with employees that the employer is more likely to hire a person who already knows someone who works in the firm.

Why might market transition be associated with an increase in employers' use of network recruitment? In planned economies, firms have few incentives to hire efficiently. Most firms in planned economies operate with soft budget constraints (Kornai 1980); that is, they expect to be bailed out by the authorities if their costs exceed their revenues. With this financial protection in place, employers hoard labor to better deal with production bottlenecks and to increase their clout in the administrative hierarchy. They have little concern with efficient recruitment practices, accepting the candidates the state assigns to them and turning a blind eye to instances where job candidates enter a firm through connections (Gerber and Mayorova 2010).

Market development exposes employers to the effects of competition and hard budget constraints, and they begin to be more concerned with efficiency, including efficiency in human resource management (Nee and Opper 2012; Zhang and Lin 2016). They therefore seek out effective and low-cost ways to identify, recruit, and retain good workers, including adopting network recruitment. Network recruitment can help firms to provide information about job candidate's attributes that are hard to observe (Fernandez, Castilla, and Moore 2000; Merluzzi and Sterling 2017). It can also curb job candidate's 
opportunistic behavior (Sterling 2014). Furthermore, employees hired on the recommendation of existing employees are likely to receive mentorship and help with socialization into the organization from the referrer (Castilla 2005; Kmec 2007).

While the results of prior studies appear consistent with the argument that market transition increases network matching due to employers' adoption of network recruitment, most, if not all, prior work showing a positive association between market development and network matching is based on post-hire outcomes, i.e. asking respondents how they found their current jobs. Research in the network matching literature reveals that relying on post-hire outcomes can lead to incomplete or even misleading conclusions about pre-hire processes (e.g. Montgomery 1992; Fernandez and Weinberg 1997; Mouw 2003; Obukhova and Zhang 2017). In particular, because jobfinding studies only collect information about matches that resulted in a hire, and do so from the perspective of the hired worker, they provide limited insight on the behavior of the two other actors in network matching: the employer and the referrer (Bidwell and Fernandez-Mateo 2008; Rubineau and Fernandez 2015).

Furthermore, prior studies are not able to provide direct evidence for the proposed mechanism. The absence of direct evidence is particularly problematic given that one study (Benton et al. 2015) that has attempted to get a closer look at network recruitment from a job-finder perspective seems to suggest that in East Germany network recruitment decreased during market transition following re-unification. To study network recruitment, Benton et al. (2015) focused on those who found jobs without actively seeking work (a phenomenon also known as non-search). Research suggests that network matching is often a result of the "invisible hand of social capital," or the fact that 
exchange of information about jobs takes place in routine social interactions (e.g. Lin and Ao 2008; McDonald 2010). Benton et al. (2015) argue that employees, whose employers encourage them to share information about job openings, are more likely to occur to engage in such information-sharing.

\section{Our analytical strategy: The referrer perspective}

Despite the critical role that labor market intermediaries, including referrers, play in network matching, only in recent years have they begun to receive scholarly attention (Smith 2005; Bidwell and Fernandez-Mateo 2008; Rubineau and Fernandez 2015). Following Granovetter's (1974) lead, most research on network matching focuses on job candidates. While some studies have adopted a perspective focused on employers (e.g. Fernandez, Castilla and Moore 2000; Merluzzi and Sterling 2017), in recent years a new wave of scholarship has emerged that that focuses on formal intermediaries, such as head-hunters (e.g. Fernandez-Mateo 2007; Fernandez-Mateo and King 2011), and informal ones, which we call referrers (e.g. Smith 2005; Marin 2012; O’Connor 2013; Kim and Fernandez 2017).

Focusing on referrers allows us to empirically disentangle two possible mechanisms that shape information-sharing behavior, paving a path for reconciling conflicting expectations in the extant theory. The first mechanism is implied by the literatures on market transition and institutional holes. This literature suggests that market transition decreases individuals' propensity to share job information because as formal market intermediaries mature, individuals have less incentive to engage in informal favor exchange. The second mechanism is implied by the literature on referrals and empirical 
studies of job-finding methods in China. This literature suggests that market transition increases overall prevalence of job information-sharing because people whose employers encourage them to make referrals share information with many more people, and the number of such employers increases with market transition.

With these conflicting predictions in mind, we undertake a stepwise process of analysis that shows evidence for both mechanisms. We first provide evidence supporting the second mechanism. We begin by examining the effect of two employer-level characteristics (offering a referral bonus and being privately-owned) on the likelihood and volume of an individual's job information-sharing behavior. Prior research suggests that referral bonuses - a common component of employer network recruitment policyshould increase information-sharing (Beaman and Magruder 2015; Kim and Fernandez 2015). We also expect that employees in privately-owned firms (as opposed to organizations with significant local or national state control) are more likely to share job information. Privately-owned firms are more subject to efficiency pressures than stateowned firms and are more likely to adopt network recruitment (Gerber and Mayorova 2010; Nee and Opper 2012).

We proceed to examine how these employer effects can create a positive relationship between market development and network matching. Specifically, we test whether market development is associated with a greater number of respondents working in firms offering a referral bonus and being privately-owned. If the number of such employers is positively associated with market development, it can account for the positive relationship between market development and the prevalence of network matching found in job-finding studies. We also examine whether market development 
strengthens these employer effects - an alternative mechanism that could produce a positive relationship between market development and network matching.

Then, to provide evidence for the first mechanism, we examine the relationship between market development and job information-sharing at the individual level. These analyses shed light on how market development affects individuals' propensity to share job information net of the employer-level factors. To further explore the changing function of job information-sharing, in an extension of our main analysis, we investigate the relationship between market development and recipients' characteristics, distinguishing information-sharing with contacts who are weak vs strong ties and those who employed vs unemployed. Lastly, we examine the relationship between market development and job information-sharing about job opportunities outside of a referrer's own employer, a behavior not directly incentivized by the employer and thus likely reflecting informal favor exchange.

\section{METHOD}

\section{Data}

Our data come from the Chinese General Social Survey (CGSS), a collaborative effort led by Renmin University of China and Hong Kong University of Science and Technology in partnership with six other universities and the Shanghai Academy of Social Sciences. The data is collected biannually using a multi-stage stratified sampling design that covers 29 provincial-level units in China. This count includes 21 provinces as well as three centrally administered cities (Beijing, Shanghai, and Chongqing) and four autonomous regions (Inner Mongolia, Guangxi, Ningxia, and Xinjiang) that have the 
administrative status of provinces. This survey is one of the highest-quality surveys of households in China. Since its inception in 2003, the data it supplies has been used in more than 700 journal papers, ${ }^{2}$ including studies of social networks in labor markets (e.g., Zhao 2013; Tian and Lin 2016).

In 2012, the CGSS included a module on job-referring behavior designed by the authors and selected for inclusion through a competitive process. Respondents were asked whether their employer offered a referral bonus (this was defined in the survey as "if an employee successfully recommends someone to the firm, $\mathrm{s} / \mathrm{he}$ receives a bonus or award"), whether in the last 12 months they had passed information about a job opportunity to someone, and a series of follow-up questions about the last time they referred. Specifically, respondents who had made a referral were asked if the job opportunity was in their own firm or in another firm, about their relationship to the person to whom they passed this information, and also whether the person was unemployed. In addition, CGSS collects respondents' demographics, career history, and rich information about their social capital.

The advantages of our unique data source come at a cost. Because of the novelty of our survey module, we do not have longitudinal data. In job-finding studies that collect data at one point in time, scholars often use variation in when a person found their job to examine period effects. This is not feasible in a study about job information-sharing, because collecting retrospective information about job information-sharing in the distant past is likely to be subject to significant recall errors. Instead, we leverage interprovincial variations in market development using a measure developed by China's

\footnotetext{
${ }^{2}$ CGSS website: http://www.chinagss.org/index.php?r=index/publication. Accessed August 8, 2018.
} 
National Economic Research Institute that is commonly used to study the effects of institutional variation in China (e.g., Nee and Opper 2010; Cao and Rubin 2014; Zhang and Lin 2016). While we readily acknowledge that market transition might not neatly follow inter-provincial differences in market development, this approach allows us to hold constant macro-economic conditions that might vary in longitudinal studies.

Of the 11,765 people who participated in the survey in 2012 , roughly half $(5,818)$ received the referrer module. Because our focus is on the effects of employers' use of network recruitment on job information-sharing, we exclude those whose employer had only one employee. We also exclude those respondents who indicate that their occupation is farming, because Chinese agriculture continues to be dominated by small farms relying on family labor. This gives us a sample of 2,299 respondents.

\section{Description of variables}

Job information-sharing. The survey asked respondents whether in the last 12 months they had provided a family member, friend or acquaintance with information about a job opportunity, and if so, how many people. Using this information, we create a dependent variable shared job information, coded 1 if the respondent reported passing job information to someone in the last 12 months (28\%) and 0 otherwise (72\%) (see Table 1). We also create a count variable shared job information (count) (mean=1.38), counting the number of people with whom the respondent shared job information over the last 12 months. 
Market development. To operationalize market development, we use China's National Economic Research Institute (NERI) provincial marketization index which tracks economic and institutional measures capturing the importance of markets in resource allocation (Fan, Wang and Zhang 2011). In China, unlike in Russia or the formerly socialist countries of Eastern Europe, local experimentation has been an important driver of the reform process (Shirk 1993; Nee and Opper 2012). In general, the reforms were implemented earlier and much more extensively in the eastern coastal regions than in the western inland ones. With time, these differences have persisted and have become even more pronounced. Thus, following the lead of other work (e.g. Nee and Opper 2010; Cao and Rubin 2014; Zhang and Lin 2016), we use these enduring differences to study variation in market development.

To capture these provincial differences in market development, the National Bureau of Statistics of China creates an annual NERI index based on government statistics and NERI's surveys. The NERI index is made up of 23 indicators grouped into five sub-indexes: (1) "Government and market relations" measures the size of government, tax burdens and the role government plays in resource allocation; (2) "Development of the non-state sector" captures the size of the non-state economy as reflected in agricultural sales, fixed investments and city employment; (3) "Development of the commodity and product markets" measures the importance of markets in price setting and the absence of local trade barriers; (4) "Development of factor markets" measures the degree of competition in the finance industry as well as foreign investment, flexibility of labor movement and technological achievements; and (5) "Development of 
market institutions" captures formal intermediaries including lawyers, accountants, and the legal environment, including intellectual property and consumer rights protection. ${ }^{3}$

Firm characteristics. We include two types of firm-level variables in our models. We create a variable for referral bonus, coded $1(5 \%)$ for respondents who report that their employer offers a bonus for making a reference that fills a job vacancy and 0 otherwise. We also create a dummy variable private firm, coded $1(71 \%)$ for firms that are not state-owned and 0 otherwise. Prior research suggests that domestic privately owned firms, because they are more concerned with efficiency compared to state-owned firms, are more likely to encourage job-referring than other types of employers (Gahan, Michelotti, and Standing, 2012; Nee and Opper 2012). We code foreign-owned private firms the same way (though only 17 respondents in our sample worked for foreign-owned firms), because foreign-owned firms are likely to be as concerned with efficiency as domestic private firms. The reference category for our private firm variable includes respondents who work in government, state-owned firms, collectively owned firms, research and education organizations, and the military.

We performed a number of robustness checks on our coding of the private firm variable. Research suggests that collectively owned firms are better understood as firms run by local governments than as truly private firms (Y. Huang 2008). However, we also tried coding collectively owned firms as private. This did not substantively change our results. We also replicated our analysis coding "state," "private" and "other" as three

\footnotetext{
${ }^{3}$ In our analysis, to make our study comparable with other work, we follow a common practice of using the composite NERI index. In additional analyses, we examined separate NERI sub-indexes. We find that while the direction of effects is consistent across sub-indexes, the effect of the development of factor markets is the largest in magnitude and statistical significance. This is consistent with results reported by Zhang and Lin (2016).
} 
dummy variables. Results indicated that the effects for "other" category are in the same direction and similar in magnitude to "private," but have larger margins of error. Write-in descriptions of employers in the "Other" category indicated that these were primarily getihu, or small-scale private enterprises. Thus, the effects we find appear to occur in both small and large scale private firms.

We also include a set of firm-level controls to capture the extent to which the employer has formalized human resource (HR) management practices. The formalization of HR, including the introduction of formal tests or other relatively objective prospective employee screening techniques, might shape network recruitment independently of the employer's promotion of network recruitment. For instance, it might discourage job information-sharing if it eliminates opportunities for cronyism. We create two measures of HR formalization at the firm level. First, we create the control variable firm size (log) giving the natural logarithm of the number of employees reported to be working at the respondent's employer (mean=3.63). This measure is a commonly used proxy for employer formalization (Sorenson 2007). We also create a dummy variable for whether the firm has a written labor contract (43\%) with its employees.

Individual-level variables. We also create several individual-level controls that are known to be associated with job information-sharing and are plausibly responsive to market development. We create a control variable supervisor coded 1 if the respondent reported supervising others (28\%) and 0 otherwise. Supervisors are more likely to know about potential job opportunities and might also be in a better position to influence the outcome of the referral. We control for a person's social capital using two variables. First, using a methodology developed in Lin and Dumin (1986), we create network range 
(mean=4.05), which measures the range of occupations held by people in the respondent's social network, scored as a number out of a list of ten (professor, lawyer, nurse, computer programmer, middle school teacher, personnel manager, farmer, hairdresser, receptionist, and police officer). Also, we create a dummy variable non-kin socializing, coded $1(80 \%)$ if the respondent reports going out to eat and drink with nonkin at least occasionally, and 0 otherwise. Lastly, we create a dummy control variable network hire, coded 1 (28\%) if the respondent reports having found their current job via a social contact and 0 otherwise.

In addition, we use a variety of demographic control variables known to be relevant to labor market activity and social capital, including male (60\%) and age $($ mean $=40)$. We also include a squared term for age $\left(\operatorname{age}^{2}\right)$ to capture potential declining returns on experience. We create a number of dummy variables to capture the respondent's highest level of education. Edu: $H S$ is coded 1 (26\%) if the respondent had some secondary school education (including academic or occupational high school, trade school, and occupational middle school). Edu: College is coded 1 (30\%) if they had some post-secondary education, including occupational college and university. Edu: Least (44\%), the reference category, applies to respondents with no secondary or higher education. Han is coded $1(93 \%)$ if the respondent was of Han ethnicity, an ethnic group to which more than 90 percent of people living in China belong. Party member is coded 1 $(15 \%)$ if the respondent was a member of the Chinese Communist Party. Migrant is coded $1(16 \%)$ if the respondent indicated that their residential registration (hukou) was in a different province than where they currently live; it is plausible that migrants have less social capital in the cities where they live compared with non-migrants (Lu, Ruan 
and Lai 2013). Urban is coded 1 (52\%) if the respondent indicated that they reside in an urban area.

\section{RESULTS}

\section{Network recruitment and job information-sharing}

The regression models presented in Table 2 estimate the antecedents of sharing job information for the binary shared job information variable. Model 1 of Table 2 presents coefficient estimates from the job information-sharing model using only the control variables. In Model 2, we add our independent variable, province marketization. Although the point estimate for province market development has a negative sign, the coefficient is not significantly different from zero, indicating no significant overall association between market development and job information-sharing. We then examine how employer-level variables that we expected to be associated with employers using network recruitment shape job information-sharing by introducing referral bonus and private firm to the null model separately (Models 3 and 4) and jointly (Model 5).

Together, the models indicate that both these firm characteristics are significantly and positively associated with job information-sharing.

In Model 6 we add market development to the model along with controls and employer-level terms. The result in Model 6 of Table 1 shows that market development has a significant negative association with job information-sharing. Also note that when market development is included in the model, both employer-level characteristics (referral bonus and private) continue to be associated with a higher likelihood of job information-sharing. These effects are substantively similar in Model 7, where we also 
add industry fixed effects. Together these results present strong evidence that people who work in firms that offer a referral bonus and in private firms participate in higher levels of job information-sharing. Consistent with theories predicting the decline in informal favor exchanges as market intermediaries mature, we also find some evidence that net of employer effects and other controls, market development is negatively associated with job information-sharing.

\section{<Insert Table 2 Here>}

Next, we use zero-inflated negative binomial models of the count variable shared job information (count). These results, presented in Table 3, show the same overall pattern as the results for the binary variable in Table 2, but with stronger statistical significance. Model 2 shows an initial significant negative association between market development and the number of times a person shares job information. Models 3, 4 and 5 of Table 3 indicate that working for a private firm or a firm offering a referral bonus increases the number of times that a respondent shares job information. While Model 2 indicates that market development is significantly and negatively associated with the number of times that a respondent shares job information-even without the employerlevel terms - as Model 6 reveals, the magnitude and significance of the association grows with the inclusion of employer-level terms. These results are not substantively affected by the inclusion of industry controls in Model 7.

\section{<Insert Table 3 Here>}

We also tested for the interaction between market development and employer variables in models with binary and count-dependent variables. Neither interaction was significant in either model. The absence of any significant interactions means that 
network recruitment appears to operate in similar ways across institutional contexts. That is, an employer offering a referral bonus appears to provide employees with a similar motivational incentive to share job information regardless of whether they are in a province with a more- or less-developed market. Further, our results suggest that privately-owned firms appear to foster job information-sharing in a similar manner across provinces regardless of market development.

If the interaction terms are insignificant, why is there more network matching in provinces with more developed markets? The key is that in provinces with greater market development, there are more firms with referral bonuses and more privately-owned firms. And since people who work at firms offering a referral bonus and at private firms are more likely to share information and share it with more people, we expect the overall prevalence of job information-sharing to increase with an increase in the number of such employers. We provide preliminary evidence for this by estimating multivariate models predicting that a person works for a privately-owned firm or a firm offering a bonus using the same covariates included in Table 2. The results, presented in Table 4, indicate that net of individual characteristics, provincial market development is indeed positively associated with the likelihood that an individual works in a private firm or a firm offering a referral bonus.

\section{<Insert Table 4 Here>}

Taken together, these results suggest that the increase in network matching associated with market development found in prior job-finding studies is due to an increase in the number of employers adopting practices encouraging employees to refer, rather than to an independent increase in individuals' propensity to share job information. 
Specifically, we show that employees in firms offering referral bonuses and in private firms are more likely to share job information and do so with more people than employees in firms without a referral bonus or in non-private firms. And respondents in provinces with more developed markets are more likely to work in a firm that offers a referral bonus or in a private firm. These two factors combine to create a positive association between market development and network matching.

We also find that, net of these employer effects, market development is negatively associated with individual's job information-sharing. Despite this, the effect of market development in terms of change in the composition of the employer population (i.e., more firms offering a referral bonus or more privately-owned firms) can lead to an increase in the overall prevalence of network matching. Recall that Table 3 reveals that the coefficient for working at a private firm or a firm with a referral bonus is large, but the one for working in a more marketized context is small. This means that with marketization, even though on average the likelihood of sharing job information decreases, those people who work at private firms or firms with a referral bonus share information with many more people. In this way, as the number of firms that encourage employees to share information about job opportunities increase, the overall prevalence of network matching increases in spite of the marketization effect.

\section{Extensions: Changing function of job information-sharing}

Our analysis revealed that net of employer effects, the association between market development and job information-sharing is significant and negative (though smaller in size than the positive employer effects). What might account for this finding? To begin 
answering this question, we explore the relationship between market development and 1) who is the recipient of the information and 2) whether the information is about employment opportunities with employer's other than referrer's own employer.

Specifically, for those who shared information with someone (625 respondents), we create three binary dependent variables. Shared with a strong tie is coded $1(69 \%)$ if the respondent reported passing job information to a job-seeker who is a strong tie (a family member or a friend) and coded 0 otherwise. Shared with an unemployed contact is coded $1(72 \%)$ if the respondent reported passing job information to a job-seeker who is currently unemployed, and 0 otherwise. Shared about another employer is coded 1 (64\%) if a respondent reported referring to a position outside of their own employer, and 0 otherwise.

As not all respondents choose to share job information, we condition on sharing of job information. Conditioning on job information-sharing creates the possibility of a selection bias that must be accounted for in our analyses. We use an inverse-probability weighting approach that effectively creates a pseudo-population of observations, conditioned on observables that would be obtained if job information-sharing occurred randomly (Woolridge 2007; Cole and Hernán 2008). Because we observe the characteristics of respondents who do not share as well as those who do, we can use this inverse-probability weight method rather than rely on selection-adjustment methods that assume the selection process is not observed (e.g., Heckman 2SLS). Accordingly, in these analyses, we use the results of analyses for the binary shared job information variable to correct for selection effects. Specifically, we weight our logistic regression 
models with the inverse probability of job information-sharing calculated for each respondent, using the coefficient estimates presented in Model 7 of Table 2.

The results are presented in Table 5. We find a consistent negative relationship between market development and job information-sharing with strong ties (Model 1), with unemployed job candidates (Models $2 \& 3$ ), and about job opportunities at employers other than the referrer's own (Model 4). As an additional robustness check, in Model 3 we examine the relationship between market development and referring unemployed job candidates with a control for the provincial level of unemployment. Consider that it is possible that provincial market development is associated with lower provincial unemployment. If this is the case, provinces with more developed markets might have fewer unemployed job candidates than provinces with less developed markets. Model 3 suggests that the provincial level of unemployment has a marginally significant negative effect on the likelihood of job information-sharing with unemployed people, but even with the inclusion of the control for provincial unemployment, the effect of provincial development is not diminished in terms of its significance or magnitude.

\section{<Insert Table 5 Here>}

Figure 1 represents graphically the results from the three sets of analyses in Table 5. Recall that based on the results presented in Model 5 of Table 2, we observe a decline in the likelihood of job information-sharing over the observed range of market development. Using the estimates in Models 1, 2, and 4 from Table 5, we can now decompose job information-sharing trends based on who is the recipient of the information and whether the information is about employment opportunities with referrer's own employer. In each panel of Figure 1, the lighter gray portion at the top of 
the graph shows the trend for the job information-sharing recipients (contacts who are strong ties or who are unemployed), and job information-sharing about positions outside of the referrer's own employer. The darker gray portion at the bottom of each graph shows the reference group. The consistent pattern revealed in all three panels is that sharing information with strong ties, unemployed contacts and about opportunities outside of referrer's own employer are negatively associated with market development.

<Insert Figure 1 Here>

These results point to a change in the function of job information-sharing in China from a process driven by social obligation to one that reflects employers' hiring needs (Guthrie 1998; Chang 2011). We expect that sharing information with strong ties is more likely to be driven by a sense of social obligation than sharing information with weak ties (Obukhova 2012; O’Connor 2013; Kim and Fernandez 2017). Similarly, sharing information with unemployed contacts - who have the greatest and most obvious need for job assistance - is more likely driven by social obligation than sharing job information with employed contacts (Granoveter 1983; Marin 2012). We find that information sharing with strong ties and unemployed contacts declines most rapidly. We also find that people are less likely to share job information about opportunities outside of their employer. This finding also points to a decline in the importance of social obligation as a driver of information sharing, since this behavior lacks the incentive of an employersponsored referral program. Instead, as documented in the previous section, we observe an increase in job information-sharing that reflects employers' encouragement of this practice. 
We also note that while market development has consistent effects in these models, employer-level variables have inconsistent effects. Regarding bonuses, we find that the presence of a referral bonus has no effect on job information-sharing with strong ties or sharing of information about job opportunities outside of the employer, and it has a negative effect on job information-sharing with unemployed job candidates. It is possible that referrers might perceive unemployed job candidates as being less hirable, and as a result might be less likely to refer them to formal referral programs. Regarding private firms, we find that employees at private firms are more likely to refer strong ties. This is consistent with work that suggests that private firms rely on family and relatives for recruitment of low-skilled workers (e.g. Nee and Opper 2012). We also find that employees at private firms are less likely to share job information with an unemployed person or about a position outside of their employer.

\section{DISCUSSION AND IMPLICATIONS}

In this study, we leverage a unique data set on job information-sharing behavior to provide pre-hire insights into how market development shapes network matching. Our results provide important evidence that the increase in network matching found in prior job-finding studies is likely due to an increase in the number of employers adopting practices encouraging employees to share job information with their contacts. Net of these employer effects, market development is negatively associated with individuals' propensity to share job information. In this way, our results help to reconcile two apparently conflicting theoretical predictions about the relationship between network 
matching and market transition. More broadly, our study enriches our understanding of how network matching responds to institutional change.

Our results provide preliminary evidence for the change in the function of job information-sharing during transition, and in this way contributes to the debate surrounding the decline of guanxi (see Guthrie 1998, Chang 2011; Bian 2018, 2019). Our results point to an important difference in the nature of network matching in provinces with more- versus less-developed markets. Specifically, in provinces with moredeveloped markets, marketization is negatively associated with information-sharing with strong ties, unemployed contacts, and to job opportunities outside of one's employer. Together with our findings about employer-side effects, these results suggest that network matching in China is changing from a norm where referrers help job-seekers find desirable jobs for reasons of social obligation (Bian 1994; Obukhova 2012), to one where employers leverage the social capital of their employees to circulate information about job opportunities to potential job candidates for reasons of economic efficiency (Zhao 2013; X. Huang 2017).

More broadly, our study highlights the potential theoretical benefits of studying network matching from the referrer perspective. To date, most research on social networks in labor markets has focused either on job candidates or on employers' use of referrals (e.g., Pellizzari 2010; Merluzzi and Sterling 2017). However, there is growing recognition in the literature that accurate models of network-based matching require an understanding of the entire triad of agentic decision-makers: the employer, the job candidate and the intermediary (Bidwell and Fernandez-Mateo 2008; Rubineau and Fernandez 2015). Together with an emerging literature that focuses on formal (e.g. 
Fernandez-Mateo and King 2011) and informal labor market intermediaries (e.g. Smith 2005; Marin 2012), our study highlights how adopting a referrer's perspective can complement and enrich existing theories.

Our results also help to explain conflicting findings in studies of network matching in different transition economies (and in particular, East Germany vs China and Russia). Our results suggest that to understand the prevalence of network matching, it is important to empirically examine the underlying mechanisms, in particular how each country's transition shapes employers' use of network recruitment. Evidence suggests that in China and Russia, as the economy transitioned to liberal markets, more employers adopted network hiring (e.g. Gerber and Mayorova 2010; Nee and Opper 2012). This likely explains why studies conducted in these two countries find a positive relationship between market transition and network matching. In contrast, in East Germany, where the economy transitioned to coordinated markets, employers have decreased the use of networks in hiring. This might explain why in German studies market transition appears to be associated with a decrease in network matching (Benton et al. 2015).

Our results also raise a number of questions for future research. Our data was collected before mobile social media became widespread in China. Given this timing, it is perhaps not surprising that we find no relationship between "internet use" and job information-sharing in our data (analyses available from the author upon request). However, by reducing the costs of sharing information, social media can make it easier, and may potentially increase network matching. Anecdotally, in China the development of the wechat social media platform, which allows users to instantaneously share information about job openings with a large number of "group" members, dramatically 
increases job information-sharing. Yet, we expect that the key insight of our paper-that employers' hiring practices are an important driver of such job information-sharing behavior-will remain relevant even with the introduction of online platforms.

Our results also suggest the need for future research to examine the relationship between institutional environment and who is receiving job information. Prior research suggests that employer referral incentives can lower the quality of referred job candidates (Fafchamps and Moradi 2015; Bond, Labuzova and Fernandez 2018), but it has little to say about the role of institutions in this process. Though we do not measure referral quality, our study reveals a strong effect of the institutional environment on with whom people share information. Specifically, job information-sharing with strong ties or unemployed contacts both decrease with marketization. In contrast to these consistent effects, we found that employer characteristics have inconsistent effects on the type of information-sharing. These results suggest the need for future research to investigate direct effects of the institutional environment on referral quality and whether the incentives-quality tradeoff might be context-specific.

Our results offer practical lessons for employers who wish to use formal referral programs in hiring. Prior research suggests that incentives can encourage referrals (e.g. Beaman and Magruder 2015; Kim and Fernandez 2015). Extending this prior work, our study finds that these effects are robust to substantial institutional differences, such as those that exist between more- and less-marketized provinces. Specifically, we found that working for a firm with a referral bonus and working in a private firm had similar effects on the likelihood of referring and referral frequency across provinces with different levels 
of market development. This is good news for employers who consider using referrals in real-world organizations. 


\section{REFERENCES}

Beaman, Lori, and Jeremy Magruder. 2012. Who gets the job referral? Evidence from a social networks experiment. American Economic Review 102(7): 3574-93.

Benton, Richard A., Steve McDonald, Anna Manzoni, and David F. Warner. 2015. The recruitment paradox: Network recruitment, structural position, and East German market transition. Social Forces 93(3): 905-32.

Bian, Yanjie. 1994. Guanxi and the allocation of urban jobs in China. China Quarterly (140): 971-99.

Bian, Yanjie. 1997. Bringing strong ties back in: Indirect ties, network bridges, and job searches in China. American Sociological Review 62(3): 366-85.

Bian, Yanjie. 2002. Institutional holes and job mobility processes: Guanxi mechanisms in China's emergent labor market. Pp. 117-35 in Social Connections in China: Institutions, Culture, and the Changing Nature of Guanxi, edited by T. Gold et al. New York: Cambridge University Press.

Bian, Yanjie. 2018. The prevalence and the increasing significance of guanxi. China Quarterly 235(Sept): 597-621.

Bian, Yanjie J. 2019. Guanxi: How China Works. Oxford, UK: Polity Press.

Bidwell, Matthew, and Isabelle Fernandez-Mateo. 2008. Three's a crowd? Understanding triadic employment relationships. Pp. 142-78 in Employment Relationships: New Models of White-Collar Work, edited by Peter Cappelli. Cambridge: Cambridge University Press.

Bond, Brittany M., Tatiana Labuzova, and Robert M. Fernandez. 2018. At the expense of quality. Sociological Science (5): 380-401.

Borocz, Jozsef, and Caleb Southworth. 1998. 'Who you know': Earnings effects of formal and informal social network resources under late state socialism in Hungary, 19861987. Journal of Socio-Economics 27(3): 401-25.

Cao, Yang, and Beth A. Rubin. 2014. Market transition and the deinstitutionalization of standard work hours in post-socialist China. ILR Review, 67(3): 864-890.

Castilla, Emilio J. 2005. Social networks and employee performance in a call center. American Journal of Sociology 110(5): 1243-83.

Chang, Kuang-Chi. C. 2011. A path to understanding guanxi in China's transitional economy: Variations on network behavior. Sociological Theory, 29(4): 315-339.

Cole, Stephen R., and Miguel A. Hernan. 2008. Constructing inverse probability weights for marginal structural models. American Journal of Epidemiology 168(6): 656-64.

Fafchamps, Marcel, and Alexander Moradi. 2015. Referral and job performance: Evidence from the Ghana colonial army. Economic Development and Cultural Change 63(4): 715-51.

Fan, Gang, Xiaolu Wang, and Hengpeng Zhu. 2011. NERI Index of Marketization of China's Provinces, 2011 Report. Beijing: Economic Science Press (in Chinese). 
Fernandez, Roberto M., and Nancy. 1997. Sifting and sorting: Personal contacts and hiring in a retail bank. American Sociological Review 62(6): 883-902.

Fernandez, Roberto M., Emilio J. Castilla, and Paul Moore. 2000. Social capital at work: Networks and employment at a phone center. American Journal of Sociology 105(5): 1288-356.

Fernandez-Mateo, Isabel. 2007. Who pays the price of brokerage? Transferring constraint through price setting in the staffing sector. American Sociological Review 72(2):291-317.

Fernandez-Mateo, Isabel, and Zella King. 2011. Anticipatory sorting and gender segregation in temporary employment. Management Science 57(6): 989-1008.

Gahan, Peter, Marco Michelotti, and Guy Standing. 2012. The diffusion of HR practices in Chinese workplaces and organizational outcomes. ILR Review, 65(3): 651-685.

Gerber, Theodore P., and Olga Mayorova. 2010. Getting personal: Networks and stratification in the Russian labor market, 1985-2001. American Journal of Sociology 116(3): 855-908.

Granovetter, Mark. 1974 (1995). Getting a Job: A Study of Contacts and Careers. Harvard University Press.

Granovetter, Mark, 1983. The strength of weak ties: a network theory revisited.

Sociological Theory 1, 201-233.

Guthrie, Douglas. 1998. The declining significance of Guanxi in China's economic transition. China Quarterly 154(June): 254-82.

Hanser, Amy. 2002. Youth job searches in urban China: The use of social connections in a changing labor market. Pp. 137-62 in Social Connections in China: Institutions, Culture, and the Changing Nature of Guanxi, edited by David Wank, Doug Guthrie, and Thomas Gold. Cambridge: Cambridge University Press.

Huang, Xianbi. 2017. Market penetration, institutional niches and job searches in reforming China. China Quarterly, 232(June): 1070-1093.

Huang, Yasheng. 2008. Capitalism with Chinese Characteristics: Entrepreneurship and the State. Cambridge, MA: Cambridge University Press.

Kim, Minjae, and Roberto M. Fernandez. 2017. Strength matters: Tie strength as a causal driver of networks' information benefits. Social Science Research 65(July): 268-81.

Kmec, Julie A. 2007. Ties that bind? Race and networks in job turnover. Social Problems 54(4): 483-503.

Kornai, Janos. 1980. The Economics of Shortage, vol. 2. Amsterdam: North Holland.

Lebedeva, Alena. 1998. Russia's Economy of Favours: Blat, Networking, and Informal Exchange. Cambridge: Cambridge University Press. 
Lin, Nan, and Dan Ao. 2008. The invisible hand of social capital: An exploratory study Pp. 107-32 in Social Capital: An International Research Program, edited by Nan Lin and Bonnie H. Erickson. Oxford, UK: Oxford University Press.

Lin, Nan, and Mary Dumin. 1986. Access to occupations through social ties. Social Networks 8(4): 365-85.

Loury Datcher, Linda. 2006. Some contacts are more equal than others: Informal networks, job tenure, and wages. Journal of Labor Economics 24(2): 299-318.

MacKinnon, David. 2012. Introduction to statistical mediation analysis. Routledge.

Marin, Alexandra. 2012. Don't mention it: Why people don't share job information, when they do, and why it matters. Social Networks 34(2): 181-92.

McDonald, Steve. 2010. Right place, right time: Serendipity and informal job matching. Socio-Economic Review 8(2): 307-31.

McDonald, Steve, Richard A. Benton, and David F. Warner. 2012. Dual embeddedness: Informal job matching and labor market institutions in the United States and Germany. Social Forces 91(1): 75-97.

Merluzzi, Jennifer and Adina Sterling. 2017. Lasting effects? Referrals and career mobility of demographic groups in organizations. ILR Review, 70(1): 105-131.

Michailova, Snejina, and Verner Worm. 2003. Personal networking in Russia and China: Blat and Guanxi. European Management Journal 21(4): 509-19.

Montgomery, James D. 1992. Job search and network composition: Implications of the strength-of-weak-ties hypothesis. American Sociological Review 57(5): 586-96.

Mouw, Ted. 2003. Social capital and finding a job: Do contacts matter? American Sociological Review 68(6): 868-98.

Nee, Victor. 1989. A theory of market transition: From redistribution to markets in state socialism. American Sociological Review 54(5): 663-81.

Nee, Victor, and Sonja Opper. 2010. Political capital in a market economy. Social Forces 88(5): 2105-32.

Nee, Victor, and Sonja Opper. 2012. Capitalism from Below: Markets and Institutional Change in China. Cambridge, MA: Harvard University Press.

Obukhova, Elena. 2012. Motivation vs. relevance: Using strong ties to find a job in urban China. Social Science Research 41(3): 470-80.

Obukhova, Elena, and Letian Zhang. 2017. Social capital and job search in urban China: The strength-of-strong-ties hypothesis revisited. Chinese Sociological Review 49(4): 340-61.

O'Connor, Lindsey T. 2013. Ask and you shall receive: Social network contacts' provision of help during the job search. Social Networks 35(4): 593-603.

Pellizzari, Michele. 2010. Do friends and relatives really help in getting a good job? ILR Review, 63(3): 494-510. 
Rubineau, Brian, and Roberto M. Fernandez. 2015. How do labor market networks work? Pp. 1-15 in Emerging Trends in the Social and Behavioral Sciences, edited by R. A. Scott, R. H. Scott, and S. M. Kosslyn. Hoboken, NJ: John Wiley \& Sons.

Shirk, Susan. 1993. The Political Logic of Economic Reform in China. Berkeley, CA: University of California Press.

Smith, Sandra S. 2005. 'Don't put my name on it': Social capital activation and jobfinding assistance among the black urban poor. American Journal of Sociology 111(1): 1-57.

Sterling, Adina D. 2014. Friendships and search behavior in labor markets. Management Science, 60(9): 2341-2354.

Tian, Felicia F., and Nan Lin. 2016. Weak ties, strong ties, and job mobility in urban China: 1978-2008. Social Networks 44(January): 117-29.

Volker, Beate, and Henk Flap. 1999. Getting ahead in the GDR: Social capital and status attainment under communism. Acta Sociologica 42(1): 17-34.

Walder, Andrew G. 1986. Communist Neo-traditionalism: Work and Authority in Chinese Industry. Berkeley, CA: University of California Press.

Wooldridge, Jeffrey. 2007. Inverse probability weighted estimation for general missing data problems. Journal of Econometrics 141(2): 1281-1301.

Yakubovich, Valery, and Irina Kozina. 2000. The changing significance of ties - An exploration of the recruitment channels in the Russian transitional labor market. International Sociology 15(3): 479-500.

Yakubovich, Valery. 2005. Weak ties, information, and influence: How workers find jobs in a local Russian labor market. American Sociological Review 70(3): 408-21.

Zhang, Yanlong, and Nan Lin. 2016. Recruitment for networks: Social capital and staffing practices in transitional China. Human Resource Management, 55(4): 615635.

Zhao, Wei. 2013. Social networks, job search, and job earnings in a transitional economy: An institutional embeddedness argument. Pp. 103-32 in Networks, Work and Inequality, edited by S. McDonald. Bingley, UK: Emerald. 
This is the accepted verison of the article "Obukhova E, Rubineau B. Market Transition and Network-Based Job Matching in China: The Referrer Perspective. ILR Review. July 2020. doi:10.1177/0019793920937234" this version is licensed under a CC-BY-NC-ND license

Figure 1. Provincial marketization and the likelihood of three types of information-sharing. Estimates based on results reported in Table 5.
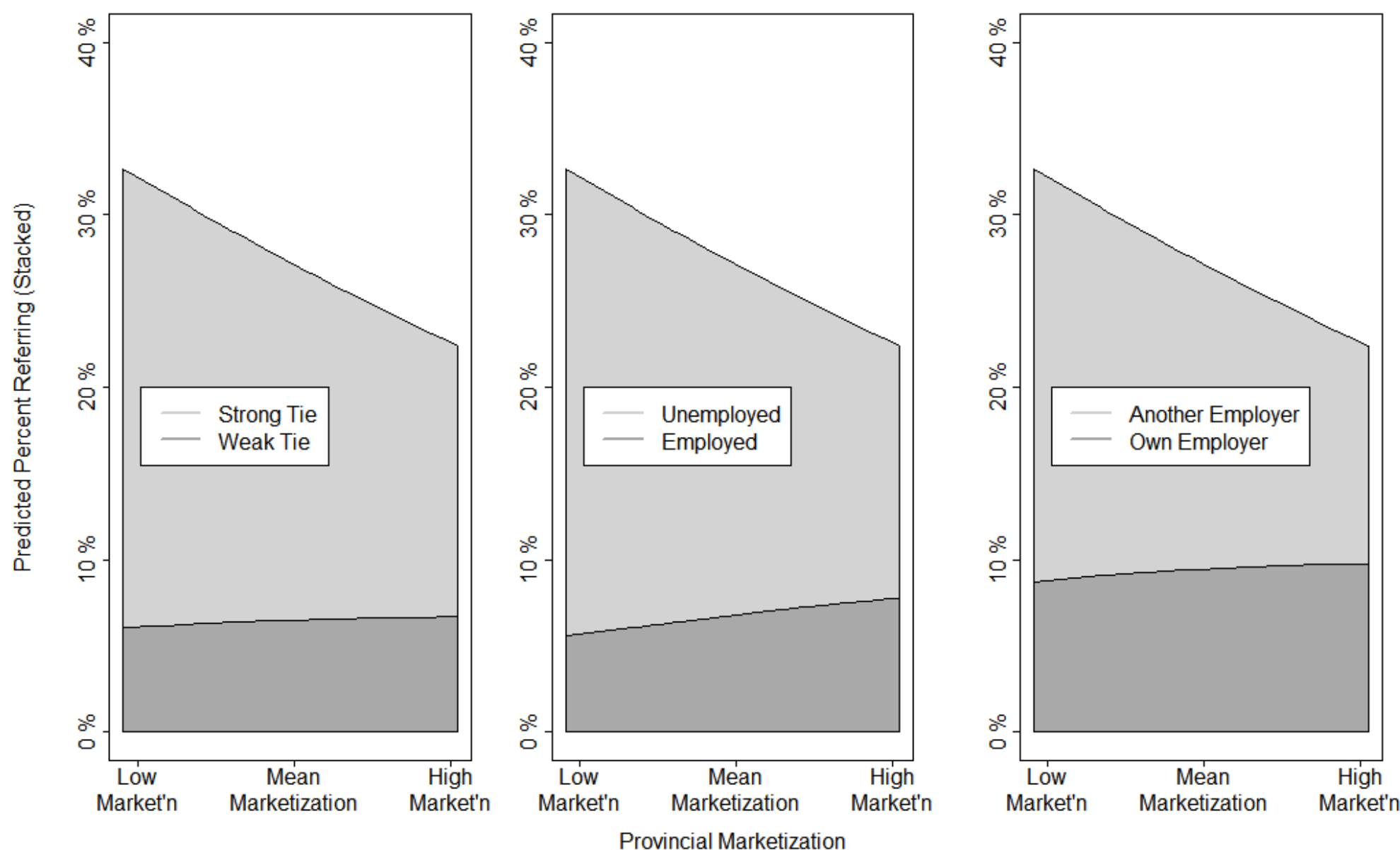
Table 1. Descriptive statistics of and correlations among the variables used in analyses.

\begin{tabular}{|c|c|c|c|c|c|c|c|c|c|c|c|c|c|}
\hline & Variable & $\mathbf{N}$ & Mean & SD & (1) & (2) & (3) & (4) & (5) & (6) & (7) & (8) & (9) \\
\hline (1) & Shared job information & 2,231 & 0.28 & - & & & & & & & & & \\
\hline (2) & Shared job info (count) & 2,224 & 1.38 & 6.83 & 0.33 & & & & & & & & \\
\hline & Shared job information: & & & & & & & & & & & & \\
\hline (3) & w/ a strong tie & 618 & 0.69 & - & - & -0.02 & & & & & & & \\
\hline (4) & w/ unemployed contact & 615 & 0.72 & - & - & -0.03 & 0.09 & & & & & & \\
\hline (5) & about other employer & 613 & 0.64 & - & - & 0.02 & -0.02 & -0.09 & & & & & \\
\hline (7) & Male & 2,231 & 0.6 & - & 0.04 & 0.05 & 0.06 & 0.01 & -0.04 & & & & \\
\hline (6) & Age & 2,231 & 40.4 & 11.2 & -0.13 & 0.02 & -0.04 & -0.18 & 0.11 & 0.14 & & & \\
\hline (8) & $\mathrm{Age}^{2}$ & 2,231 & 1,755 & 953 & -0.13 & 0.01 & -0.03 & -0.17 & 0.11 & 0.15 & 0.99 & & \\
\hline (9) & Edu: High School & 2,230 & 0.26 & - & -0.02 & -0.01 & 0.02 & -0.01 & -0.03 & 0.004 & 0.02 & 0.01 & \\
\hline (10) & Edu: College & 2,230 & 0.3 & - & 0.05 & 0.001 & 0.01 & -0.06 & -0.03 & -0.06 & -0.26 & -0.26 & -0.39 \\
\hline (11) & Han & 2,230 & 0.93 & - & -0.01 & -0.004 & -0.03 & 0.03 & -0.05 & 0.001 & 0.05 & 0.04 & -0.01 \\
\hline (12) & Party member & 2,227 & 0.15 & - & -0.01 & 0.02 & 0.06 & -0.13 & 0.06 & 0.13 & 0.12 & 0.12 & -0.06 \\
\hline (13) & Migrant & 2,229 & 0.16 & - & 0.07 & -0.001 & -0.04 & 0.06 & -0.05 & -0.05 & -0.2 & -0.18 & -0.04 \\
\hline (14) & Urban & 2,226 & 0.52 & - & -0.04 & 0.02 & -0.03 & 0.05 & 0.002 & 0.1 & 0.07 & 0.08 & -0.08 \\
\hline (15) & Supervisor & 2,225 & 0.28 & - & 0.16 & 0.1 & 0.01 & -0.1 & -0.08 & 0.14 & -0.04 & -0.06 & -0.03 \\
\hline (16) & Network range & 2,218 & 4.05 & 2.62 & 0.23 & 0.08 & 0.11 & -0.05 & 0.002 & 0.02 & -0.17 & -0.17 & 0.01 \\
\hline (17) & Non-kin socializing & 2,229 & 0.8 & 0.4 & 0.18 & 0.03 & 0.05 & 0.07 & -0.1 & 0.1 & -0.25 & -0.26 & 0.03 \\
\hline (18) & Network hire & 2,227 & 0.28 & - & 0.25 & 0.07 & -0.05 & 0.08 & -0.07 & 0.01 & -0.14 & -0.13 & -0.03 \\
\hline (19) & Firm size (ln) & 2,008 & 3.63 & 2.18 & 0.04 & 0.01 & -0.2 & -0.02 & -0.01 & 0.03 & -0.11 & -0.12 & 0.02 \\
\hline (20) & Labor contract & 2,201 & 0.43 & - & -0.002 & -0.03 & -0.11 & -0.03 & -0.04 & -0.03 & -0.1 & -0.11 & 0.04 \\
\hline (21) & Referral bonus & 2,204 & 0.05 & - & 0.2 & 0.15 & -0.06 & 0.05 & -0.1 & 0.01 & -0.09 & -0.08 & 0.002 \\
\hline (22) & Private firm & 2,104 & 0.71 & - & 0.08 & 0.03 & -0.05 & 0.1 & -0.13 & 0.01 & -0.02 & -0.01 & -0.01 \\
\hline (23) & Marketization & 2,231 & 0.31 & 2.05 & -0.02 & -0.02 & -0.07 & -0.06 & -0.12 & -0.03 & 0.03 & 0.03 & 0.03 \\
\hline (24) & Provincial unemployment & 2,112 & 3.24 & 0.66 & 0.05 & 0.04 & 0.09 & 0.07 & 0.01 & 0.06 & 0.09 & 0.09 & -0.03 \\
\hline
\end{tabular}


Table 1. Descriptive statistics of and correlations among the variables used in analyses (continued).

\begin{tabular}{|c|c|c|c|c|c|c|c|c|c|c|c|c|c|c|c|}
\hline & Variable & (10) & (11) & (12) & (13) & (14) & (15) & (16) & (17) & (18) & (19) & (20) & (21) & (22) & (23) \\
\hline (10) & Edu: College & & & & & & & & & & & & & & \\
\hline (11) & Han & 0.03 & & & & & & & & & & & & & \\
\hline (12) & Party member & 0.28 & -0.02 & & & & & & & & & & & & \\
\hline (13) & Migrant & 0.05 & -0.002 & -0.04 & & & & & & & & & & & \\
\hline (14) & Urban & -0.26 & 0.03 & -0.1 & -0.09 & & & & & & & & & & \\
\hline (15) & Supervisor & 0.25 & 0.02 & 0.22 & 0.04 & -0.13 & & & & & & & & & \\
\hline (16) & Network range & 0.31 & -0.04 & 0.15 & 0.05 & -0.13 & 0.23 & & & & & & & & \\
\hline (17) & Non-kin socializing & 0.24 & 0.05 & 0.11 & 0.06 & -0.11 & 0.21 & 0.27 & & & & & & & \\
\hline (18) & Network hire & 0.01 & 0.02 & -0.05 & 0.05 & 0.03 & 0.02 & 0.11 & 0.11 & & & & & & \\
\hline (19) & Firm size (ln) & 0.32 & 0.05 & 0.15 & -0.02 & -0.22 & 0.08 & 0.12 & 0.12 & 0.06 & & & & & \\
\hline (20) & Labor contract & 0.38 & 0.09 & 0.14 & -0.02 & -0.23 & 0.11 & 0.14 & 0.14 & 0.03 & 0.54 & & & & \\
\hline (21) & Referral bonus & 0.06 & -0.01 & 0.04 & 0.04 & -0.05 & 0.08 & 0.1 & 0.06 & 0.11 & 0.15 & 0.08 & & & \\
\hline (22) & Private firm & -0.34 & -0.02 & -0.26 & 0.11 & 0.18 & -0.07 & -0.15 & -0.13 & -0.0003 & -0.43 & -0.42 & -0.003 & & \\
\hline (23) & Marketization & 0.09 & 0.25 & -0.03 & 0.13 & -0.15 & 0.06 & -0.02 & 0.06 & -0.02 & 0.12 & 0.19 & 0.06 & 0.02 & \\
\hline (24) & Provincial unemployment & -0.18 & -0.11 & 0.01 & -0.11 & 0.12 & -0.03 & 0.04 & -0.02 & 0.06 & -0.16 & -0.23 & -0.02 & 0.03 & -0.44 \\
\hline
\end{tabular}


Table 2. Logistic regression predicting the likelihood of job information-sharing. The estimated parameters for the following control variables, none of which show any significance in any of these models, are omitted from the table for space, but are available upon request: Age, Age2, Han, Migrant, Urban.

\begin{tabular}{|c|c|c|c|c|c|c|}
\hline DV: Job information-sharing & (1) & (2) & (3) & (4) & (5) & (6) \\
\hline \multicolumn{7}{|l|}{ Control Variables } \\
\hline \multirow[t]{2}{*}{$\overline{\text { Male }}$} & 0.06 & 0.06 & 0.05 & 0.04 & 0.04 & 0.11 \\
\hline & $(0.12)$ & $(0.12)$ & $(0.12)$ & $(0.12)$ & $(0.12)$ & $(0.13)$ \\
\hline \multirow[t]{2}{*}{ Edu:HS } & $-0.24+$ & -0.24 & -0.24 & -0.19 & -0.18 & -0.23 \\
\hline & $(0.15)$ & $(0.15)$ & $(0.15)$ & $(0.15)$ & $(0.15)$ & $(0.16)$ \\
\hline \multirow[t]{2}{*}{ Edu:College } & $-0.36^{*}$ & $-0.36^{*}$ & $-0.35^{*}$ & -0.2 & -0.18 & -0.28 \\
\hline & $(0.16)$ & $(0.16)$ & $(0.17)$ & $(0.17)$ & $(0.18)$ & $(0.18)$ \\
\hline \multirow[t]{2}{*}{ Party } & -0.18 & -0.19 & -0.22 & -0.004 & -0.07 & -0.06 \\
\hline & $(0.16)$ & $(0.16)$ & $(0.17)$ & $(0.18)$ & $(0.19)$ & $(0.19)$ \\
\hline \multirow[t]{2}{*}{ Supervisor } & $0.62 * * *$ & $0.63^{* * *}$ & $0.62 * * *$ & $0.60 * * *$ & $0.61 * * *$ & $0.61 * * *$ \\
\hline & $(0.12)$ & $(0.12)$ & $(0.12)$ & $(0.13)$ & $(0.13)$ & $(0.13)$ \\
\hline \multirow[t]{2}{*}{ Network range } & $0.16^{* * *}$ & $0.16^{* * *}$ & $0.16^{* * *}$ & $0.16^{* * *}$ & $0.16^{* * *}$ & $0.15^{* * *}$ \\
\hline & $(0.02)$ & $(0.02)$ & $(0.02)$ & $(0.02)$ & $(0.02)$ & $(0.02)$ \\
\hline \multirow[t]{2}{*}{ Non-kin socializing } & $0.66^{* * *}$ & $0.67 * * *$ & $0.66 * * *$ & $0.71 * * *$ & $0.71 * * *$ & $0.72 * * *$ \\
\hline & $(0.19)$ & $(0.19)$ & $(0.19)$ & $(0.19)$ & $(0.19)$ & $(0.19)$ \\
\hline \multirow[t]{2}{*}{ Network hire } & $0.98^{* * *}$ & $0.98 * * *$ & $0.94 * * *$ & $0.98 * * *$ & $0.94 * * *$ & $0.95 * * *$ \\
\hline & $(0.11)$ & $(0.11)$ & $(0.12)$ & $(0.12)$ & $(0.12)$ & $(0.12)$ \\
\hline \multirow[t]{2}{*}{ Firm size (ln) } & 0.01 & 0.01 & -0.01 & 0.05 & 0.03 & 0.04 \\
\hline & $(0.03)$ & $(0.03)$ & $(0.03)$ & $(0.03)$ & $(0.03)$ & $(0.04)$ \\
\hline \multirow[t]{2}{*}{ Labor contract } & -0.18 & -0.17 & -0.18 & -0.08 & -0.07 & -0.05 \\
\hline & $(0.13)$ & $(0.14)$ & $(0.14)$ & $(0.14)$ & $(0.15)$ & $(0.15)$ \\
\hline \multicolumn{7}{|l|}{ Employer-level explanatory factors } \\
\hline \multirow[t]{2}{*}{ Referral bonus } & & & $1.48^{* * *}$ & & $1.52 * * *$ & $1.59 * * *$ \\
\hline & & & $(0.24)$ & & $(0.25)$ & $(0.25)$ \\
\hline \multirow[t]{2}{*}{ Private firm } & & & & $0.70 * * *$ & $0.67 * * *$ & $0.78^{* * *}$ \\
\hline & & & & $(0.15)$ & $(0.15)$ & $(0.18)$ \\
\hline \multicolumn{7}{|l|}{ Independent Variable } \\
\hline \multirow[t]{2}{*}{ Market development } & & -0.03 & & & $-0.06^{*}$ & $-0.05+$ \\
\hline & & $(0.03)$ & & & $(0.03)$ & $(0.03)$ \\
\hline \multirow[t]{2}{*}{ Constant } & $-1.95 * *$ & $-2.00 * *$ & $-2.18 * *$ & $-2.45 * * *$ & $-2.77 * * *$ & -13.7 \\
\hline & $(0.7)$ & $(0.7)$ & $(0.72)$ & $(0.74)$ & $(0.76)$ & (882.74) \\
\hline Industry FEs & $\mathrm{N}$ & $\mathrm{N}$ & $\mathrm{N}$ & $\mathrm{N}$ & $\mathrm{N}$ & $\mathrm{Y}$ \\
\hline Observations & 1950 & 1950 & 1936 & 1847 & 1835 & 1835 \\
\hline Log Likelihood & -1019 & -1019 & -990 & -955 & -927 & -918 \\
\hline Akaike Inf. Crit. & 2070 & 2071 & 2013 & 1945 & 1892 & 1902 \\
\hline
\end{tabular}

Notes: $+p<0.10, * p<0.05, * * p<0.01, * * * p<0.001$. 
Table 3. Zero-inflated negative binomial regression predicting the count of job information-sharing. The estimated parameters for the following control variables, none of which show any significance in any of these models, are omitted from the table for space, but are available upon request: Age, Han, Migrant, Urban.

\begin{tabular}{|c|c|c|c|c|c|c|}
\hline DV: Job info sharing count & (1) & $(2)$ & (3) & (4) & (5) & $(6)$ \\
\hline \multicolumn{7}{|l|}{ Control Variables } \\
\hline \multirow[t]{2}{*}{ Male } & $0.35 * *$ & $0.35 * *$ & $0.39 * *$ & $0.36 * *$ & $0.38 * *$ & $0.45 * *$ \\
\hline & $(0.13)$ & $(0.13)$ & $(0.13)$ & $(0.14)$ & $(0.13)$ & $(0.14)$ \\
\hline \multirow[t]{2}{*}{ Max(Edu:HS, Edu:College) } & $-0.45^{* *}$ & $-0.44 * *$ & $-0.37 *$ & $-0.37 *$ & $-0.28+$ & $-0.32 *$ \\
\hline & $(0.16)$ & $(0.16)$ & $(0.16)$ & $(0.16)$ & $(0.16)$ & $(0.16)$ \\
\hline \multirow[t]{2}{*}{ Party } & 0.22 & 0.18 & 0.02 & $0.49 *$ & 0.18 & 0.18 \\
\hline & $(0.19)$ & $(0.19)$ & $(0.19)$ & $(0.2)$ & $(0.2)$ & $(0.21)$ \\
\hline \multirow[t]{2}{*}{ Supervisor } & $0.83 * * *$ & $0.85 * * *$ & $0.75^{* * *}$ & $0.75^{* * *}$ & $0.74 * * *$ & $0.77 * * *$ \\
\hline & $(0.15)$ & $(0.15)$ & $(0.15)$ & $(0.15)$ & $(0.15)$ & $(0.15)$ \\
\hline \multirow[t]{2}{*}{ Network range } & $0.18^{* * *}$ & $0.18^{* * *}$ & $0.19 * * *$ & $0.17 * * *$ & $0.18 * * *$ & $0.17 * * *$ \\
\hline & $(0.03)$ & $(0.03)$ & $(0.03)$ & $(0.03)$ & $(0.03)$ & $(0.03)$ \\
\hline \multirow[t]{2}{*}{ Non-kin socializing } & $-0.31+$ & $-0.33+$ & -0.21 & -0.21 & -0.18 & -0.11 \\
\hline & $(0.18)$ & $(0.18)$ & $(0.18)$ & $(0.18)$ & $(0.18)$ & $(0.18)$ \\
\hline \multirow[t]{2}{*}{ Network hire } & $0.61 * * *$ & $0.62 * * *$ & $0.59 * * *$ & $0.51 * * *$ & $0.48 * * *$ & $0.47 * * *$ \\
\hline & $(0.14)$ & $(0.14)$ & $(0.13)$ & $(0.14)$ & $(0.14)$ & $(0.14)$ \\
\hline \multirow[t]{2}{*}{ Firm size (ln) } & -0.003 & -0.004 & -0.03 & 0.03 & -0.005 & 0.01 \\
\hline & $(0.03)$ & $(0.03)$ & $(0.03)$ & $(0.03)$ & $(0.03)$ & $(0.04)$ \\
\hline \multirow[t]{2}{*}{ Labor contract } & -0.1 & -0.05 & -0.24 & 0.003 & -0.07 & -0.07 \\
\hline & $(0.15)$ & $(0.15)$ & $(0.15)$ & $(0.16)$ & $(0.16)$ & $(0.16)$ \\
\hline \multicolumn{7}{|c|}{ Employer-level explanatory factors } \\
\hline \multirow[t]{2}{*}{ Referral bonus } & & & $1.41 * * *$ & & $1.40 * * *$ & $1.48 * * *$ \\
\hline & & & $(0.26)$ & & $(0.26)$ & $(0.27)$ \\
\hline \multirow[t]{2}{*}{ Private firm } & & & & $0.74 * * *$ & $0.71 * * *$ & $0.84 * * *$ \\
\hline & & & & $(0.17)$ & $(0.17)$ & $(0.19)$ \\
\hline \multicolumn{7}{|l|}{ Independent Variable } \\
\hline \multirow[t]{2}{*}{ Market development } & & $-0.07 *$ & & & $-0.09 * *$ & $-0.09 * *$ \\
\hline & & $(0.03)$ & & & $(0.03)$ & $(0.03)$ \\
\hline \multirow[t]{2}{*}{ Constant } & -1.0 & -1.0 & $-0.96 *$ & $-1.10^{*}$ & $-1.66 * * *$ & -14 \\
\hline & $(0.42)$ & $(0.42)$ & $(0.42)$ & $(0.45)$ & $(0.45)$ & $(1152.98)$ \\
\hline Industry Fixed Effects & $\mathrm{N}$ & $\mathrm{N}$ & $\mathrm{N}$ & $\mathrm{N}$ & $\mathrm{N}$ & Y \\
\hline Observations & 1,944 & 1,944 & 1,930 & 1,841 & 1,829 & 1,829 \\
\hline Log Likelihood & $-2,329$ & $-2,327$ & $-2,291$ & $-2,179$ & $-2,146$ & $-2,135$ \\
\hline
\end{tabular}

Notes: $+p<0.10, * p<0.05, * * p<0.01, * * * p<0.001$. 
Table 4. Logistic regression predicting employer-level explanatory factors.

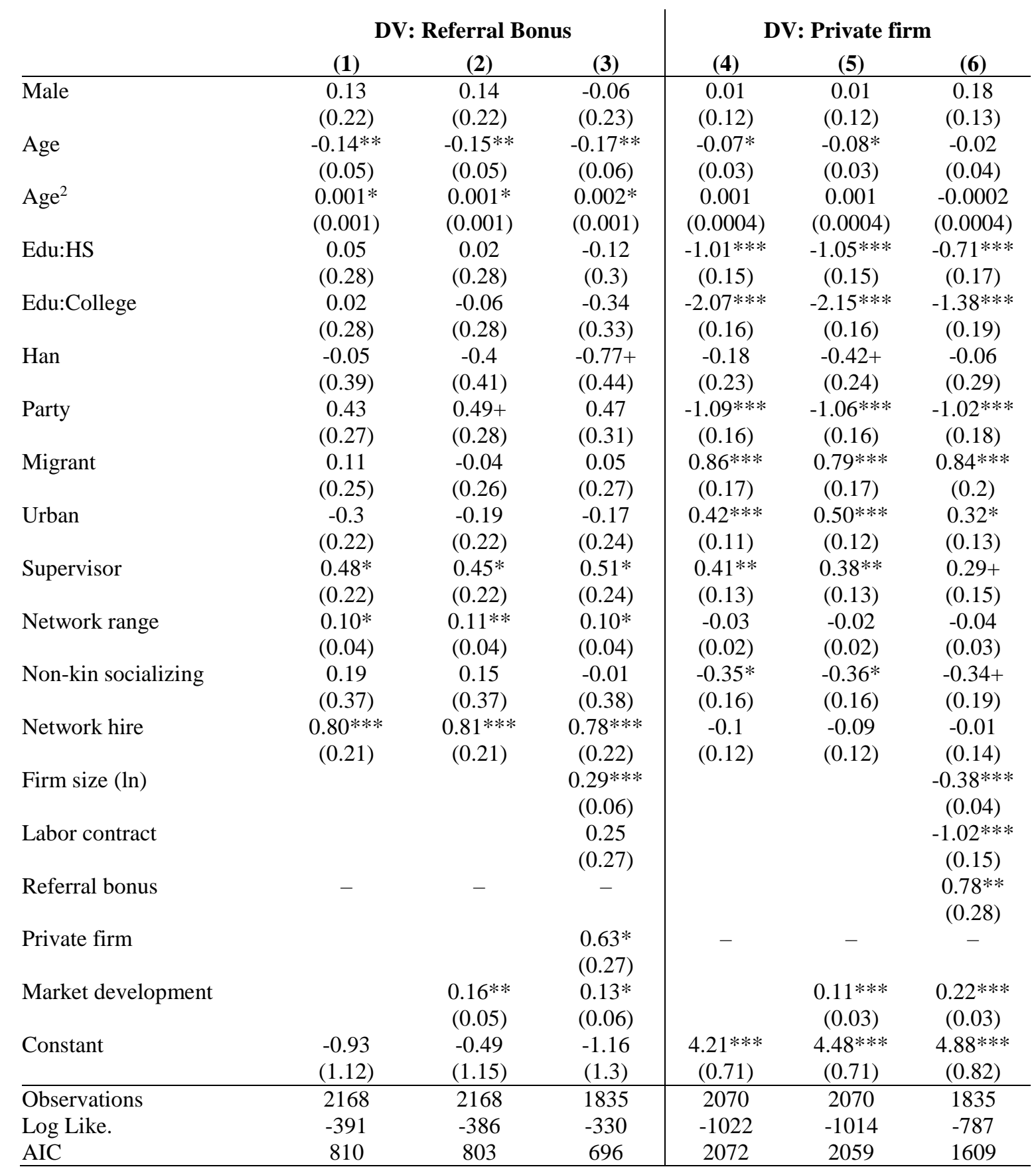

Notes: $+\mathrm{p}<0.10,{ }^{*} \mathrm{p}<0.05,{ }^{* *} \mathrm{p}<0.01,{ }^{* * *} \mathrm{p}<0.001$ 
Table 5. Logistic regression predicting the type of job information-sharing. All models condition on job information-sharing, and use inverse-probability weights from the predicted probability of sharing job information using parameter estimates from Table 2 Model 7 to address selection.

\begin{tabular}{|c|c|c|c|c|}
\hline & \multicolumn{4}{|c|}{ Shared job info } \\
\hline & \multirow{2}{*}{$\begin{array}{c}\text { w/ a strong tie } \\
\text { (1) }\end{array}$} & \multicolumn{2}{|c|}{$\begin{array}{c}\text { w/ an unemployed } \\
\text { contact }\end{array}$} & \multirow{2}{*}{$\begin{array}{c}\text { about other } \\
\text { employer } \\
\text { (4) }\end{array}$} \\
\hline & & (2) & (3) & \\
\hline \multirow[t]{2}{*}{ Male } & $0.44 * * *$ & -0.002 & 0.02 & $0.53 * * *$ \\
\hline & $(0.12)$ & $(0.12)$ & $(0.12)$ & $(0.12)$ \\
\hline \multirow{2}{*}{ Age } & $-0.20 * * *$ & 0.01 & -0.01 & -0.02 \\
\hline & $(0.04)$ & $(0.04)$ & $(0.04)$ & $(0.03)$ \\
\hline \multirow[t]{2}{*}{$\mathrm{Age}^{2}$} & $0.002 * * *$ & 0.0002 & 0.0004 & 0.0001 \\
\hline & $(0.0005)$ & $(0.0004)$ & $(0.0005)$ & $(0.0004)$ \\
\hline \multirow[t]{2}{*}{ Edu:HS } & -0.1 & $-0.27+$ & $-0.40 * *$ & $0.63^{* * *}$ \\
\hline & $(0.16)$ & $(0.15)$ & $(0.15)$ & $(0.16)$ \\
\hline \multirow[t]{2}{*}{ Edu:College } & $-0.66 * * *$ & 0.03 & -0.05 & -0.04 \\
\hline & $(0.19)$ & $(0.18)$ & $(0.19)$ & $(0.18)$ \\
\hline \multirow[t]{2}{*}{ Han } & $-1.11 * * *$ & -0.08 & -0.07 & $0.80 * * *$ \\
\hline & $(0.31)$ & $(0.25)$ & $(0.27)$ & $(0.24)$ \\
\hline \multirow[t]{2}{*}{ Party } & $-0.43 *$ & 0.09 & 0.1 & 0.22 \\
\hline & $(0.18)$ & $(0.2)$ & $(0.2)$ & $(0.19)$ \\
\hline \multirow[t]{2}{*}{ Migrant } & 0.18 & -0.04 & -0.08 & -0.06 \\
\hline & $(0.17)$ & $(0.15)$ & $(0.15)$ & $(0.16)$ \\
\hline \multirow[t]{2}{*}{ Urban } & -0.19 & -0.12 & -0.09 & $-0.58 * * *$ \\
\hline & $(0.12)$ & $(0.12)$ & $(0.12)$ & $(0.12)$ \\
\hline \multirow[t]{2}{*}{ Supervisor } & $-0.48 * * *$ & $-0.59 * * *$ & $-0.56 * * *$ & -0.2 \\
\hline & $(0.13)$ & $(0.13)$ & $(0.13)$ & $(0.13)$ \\
\hline \multirow[t]{2}{*}{ Network range } & $0.05 *$ & 0.04 & $0.05^{*}$ & $0.09 * * *$ \\
\hline & $(0.02)$ & $(0.02)$ & $(0.02)$ & $(0.02)$ \\
\hline \multirow[t]{2}{*}{ Non-kin socializing } & $0.43 * *$ & $-0.88 * * *$ & $-0.89 * * *$ & $0.31^{*}$ \\
\hline & $(0.16)$ & $(0.18)$ & $(0.18)$ & $(0.16)$ \\
\hline \multirow{2}{*}{ Network hire } & $0.29 *$ & -0.09 & -0.07 & 0.11 \\
\hline & $(0.13)$ & $(0.12)$ & $(0.12)$ & $(0.12)$ \\
\hline \multirow[t]{2}{*}{ Firm size (ln) } & 0.03 & $-0.08 *$ & $-0.06+$ & $-0.37 * * *$ \\
\hline & $(0.03)$ & $(0.03)$ & $(0.03)$ & $(0.03)$ \\
\hline \multirow[t]{2}{*}{ Labor contract } & $0.47 * *$ & 0.07 & 0.003 & -0.07 \\
\hline & $(0.15)$ & $(0.15)$ & $(0.15)$ & $(0.15)$ \\
\hline \multirow[t]{2}{*}{ Referral bonus } & 0.29 & $-0.44+$ & $-0.60 *$ & 0.19 \\
\hline & $(0.28)$ & $(0.23)$ & $(0.24)$ & $(0.25)$ \\
\hline \multirow[t]{2}{*}{ Private firm } & $0.76^{* * *}$ & $-1.32 * * *$ & $-1.28 * * *$ & $-1.08 * * *$ \\
\hline & $(0.16)$ & $(0.16)$ & $(0.17)$ & $(0.16)$ \\
\hline \multirow[t]{2}{*}{ Market development } & $-0.07 * *$ & $-0.11 * * *$ & $-0.12 * * *$ & $-0.09 * *$ \\
\hline & $(0.03)$ & $(0.03)$ & $(0.03)$ & $(0.03)$ \\
\hline Provincial unemployment & & & $\begin{array}{c}-0.17+ \\
(0.1)\end{array}$ & \\
\hline \multirow[t]{2}{*}{ Constant } & $5.28 * * *$ & $2.58 * * *$ & $3.41 * * *$ & $2.05 * *$ \\
\hline & $(0.88)$ & $(0.75)$ & $(0.85)$ & $(0.74)$ \\
\hline Observations & 504 & 503 & 482 & 507 \\
\hline Log Likelihood & -1037 & -1006 & -972 & -1041 \\
\hline AIC & 2111 & 2050 & 1984 & 2119 \\
\hline
\end{tabular}

Notes: $+p<0.10, * p<0.05, * * p<0.01, * * * p<0.001$. 